\title{
Separating agricultural and non-agricultural fire seasonality at regional scales
}

\author{
B. I. Magi ${ }^{1}$, S. Rabin ${ }^{2}$, E. Shevliakova ${ }^{2}$, and S. Pacala ${ }^{2}$ \\ ${ }^{1}$ University of North Carolina at Charlotte, Geography and Earth Sciences Department, Charlotte, North Carolina, USA \\ ${ }^{2}$ Princeton University, Department of Ecology and Evolutionary Biology, Princeton, New Jersey, USA
}

Correspondence to: B. I. Magi (brian.magi@uncc.edu)

Received: 12 April 2012 - Published in Biogeosciences Discuss.: 11 May 2012

Revised: 13 July 2012 - Accepted: 16 July 2012 - Published: 8 August 2012

\begin{abstract}
The timing and length of burning seasons in different parts of the world depend on climate, land-cover characteristics, and human activities. In this study, global burned area estimates are used in conjunction with global gridded distributions of agricultural land-cover types (defined as the sum of cropland and pasture area) to separate the seasonality of agricultural burning practices from that of non-agricultural fire. The results presented in this study show that agricultural and non-agricultural land experience broadly different fire seasonality patterns that are not always linked to climate conditions. We highlight these differences on a regional basis, examining variations in both agricultural land cover and associated cultural practices to help explain our results. While we discuss two land-cover categories, the methods can be generalized to derive seasonality for any number of land uses or cover types. This will be useful as global fire models evolve to be fully interactive with land-use and land-cover change in the next generation of Earth system models.
\end{abstract}

\section{Introduction}

Fire is a phenomenon that connects the land, the atmosphere, and the climate with human behavior in many parts of the world. Global fire models rely on climate and vegetation conditions to determine flammability and fire behavior (e.g., Arora and Boer, 2005) and now explicitly consider human population density as a source of both fire ignitions and fire suppression (e.g., Pechony and Shindell, 2009). The knowledge of spatial and temporal fire patterns has improved over the past $10-15 \mathrm{yr}$ with the development of satellite-based remote sensing methods to characterize fires at a global scale (e.g., Justice et al., 2002; Giglio et al., 2006a) and much finer scales (e.g., Morton et al., 2008; McCarty et al., 2009). Such remote sensing data are critical for parameterizing and validating fire models. However, remote sensing data products do not attribute observed fires to a specific cause, while fire models operate within a framework that must consider underlying land-cover conditions to determine the fuel load (biomass) available to burn.

Fires can be ignited by lightning, but most are a result of human practices. These include a wide range of managed activities, such as preparing cropland for planting or harvest, managing pasture for livestock or game, clearing forest for agriculture, or even unmanaged practices such as arson, accidental ignitions, or unintentional spread of managed fires into unmanaged land (Laris and Wardell, 2006; McCarty et al., 2009). Fire suppression tactics add an additional dimension to the human component of fires. Altogether, human intervention has altered the seasonality of fires in many parts of the world, both in terms of timing and magnitude (Le Page et al., 2010; Aldersley et al., 2011). A critical component of this realization is that, as suggested by Le Page et al. (2010), human burning practices do not necessarily follow the climatedriven burning season. To more completely model fires on a global scale, particularly under projected climate change (e.g., Krawchuk et al., 2009), the relationship between humans, climate, land cover, and fire needs to be better characterized.

The work presented in this study quantifies the influence of agricultural burning practices on the seasonal timing of fires. We present a method that uses satellite observations of the number of fires and burned areas in conjunction with global estimates of cropland and pasture extent to attribute 
Table 1. Descriptions of the regions.

\begin{tabular}{ll}
\hline Short Name & Full name \\
\hline BONA & Boreal North America \\
TENA & Temperate North America \\
CEAM & Central America and the Caribbean \\
NHSA & Northern Hemisphere South America \\
SHSA & Southern Hemisphere South America \\
EURO & Europe \\
MIDE & Middle East and Northern Africa \\
NHAF & Northern Hemisphere Africa \\
SHAF & Southern Hemisphere Africa \\
BOAS & Boreal Asia \\
CEAS & Central Asia \\
SEAS & Southeast Asia \\
EQAS & Equatorial Asia \\
AUST & Australia and New Zealand \\
\hline
\end{tabular}

fires and burned area to either agricultural or non-agricultural land cover. Agricultural land cover is defined as the sum of cropland and pasture area, while the remaining land area is considered non-agricultural land cover. We focus on fourteen regions around the world to investigate the fire patterns unique to each.

\section{Methods}

\subsection{Regions}

We used the fourteen regions discussed by Giglio et al. (2006b) to isolate areas of the world with similar seasonal fire patterns. Table 1 lists the names of these regions along with the shorthand notation that will be used throughout this paper, and they are shown in Fig. 1. These regions have been used by a number of global studies of fire patterns (e.g., Giglio et al., 2010; Kloster et al., 2010; van der Werf et al., 2010; Aldersley et al., 2011).

\subsection{Fire data}

Monthly burned area data at $0.5^{\circ}$ resolution are taken from the Global Fire Emissions Database (GFED) version 3 (Giglio et al., 2010). The years 2000-2009 are considered in this study. The GFED processing algorithm uses Moderate Resolution Imaging Spectroradiometer (MODIS) fire counts, surface reflectances, and land-cover characteristics to produce a burned area data set that characterizes burns as small as $1.2 \mathrm{~km}^{2}$ (Giglio et al., 2009). GFED burned area depends on fire counts (Giglio et al., 2010) derived from MODIS. Justice et al. (2002) discuss the algorithm used to process the MODIS data, and Giglio et al. (2006a) describe the MODIS fire count products themselves. Normalized mean monthly fire counts from the two MODIS instruments (Terra and Aqua) and GFED burned area are shown in Fig. 2 for the

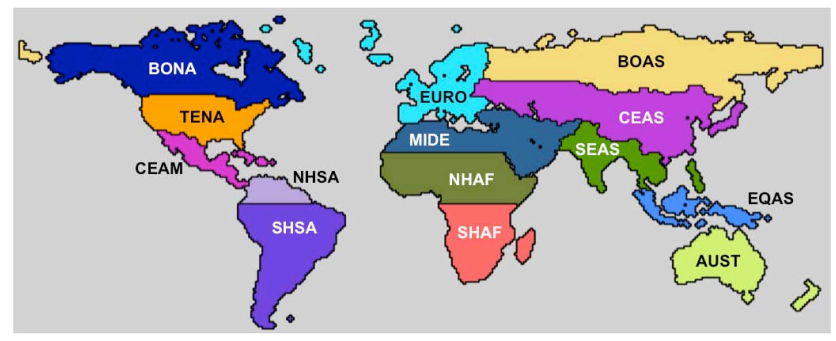

Fig. 1. Map of the regions in this study, after Giglio et al. (2006b). The short names are described in more detail in Table 1.

different regions. As expected the three datasets are closely related. The fractional contributions of the different regions shown at the top of each plot in Fig. 2 reveal differences in the regional contributions to global burned area and fire counts. This is related to differences in the two MODIS instruments (Giglio et al., 2006a) and to how the size of fires varies as a function of the vegetation being burned (Giglio et al., 2006b, 2010). We focus our discussion on burned area since it is important for quantifying fire impacts on the carbon cycle.

\subsection{Land-use data}

Cropland and pasture area are taken from the History Database of the Global Environment (HYDE) version 3.1 (Klein Goldewijk et al., 2011), which is available at five minute $\left(\sim 0.083^{\circ}\right)$ spatial resolution. In this study, we aggregate the HYDE data to $0.5^{\circ}$ resolution to match the resolution of GFED, and we define total agricultural area as the sum of cropland and pasture area. The remaining land area is considered to be non-agricultural. Annually-resolved HYDE data from 2000-2009 were obtained from K. Klein Goldewijk (personal communication, June 2012). We assume that distribution of agricultural area is constant throughout each year.

\subsection{Data analysis}

To best understand the qualitative seasonality of agricultural and non-agricultural fires, the burned area in each grid cell is normalized to its maximum value. Every grid cell, therefore, varies between zero and one regardless of the absolute magnitude of burned area in a particular grid cell. This normalization overcomes the issue of burned area patterns in a region being dominated by intense burning in one part of the region, allowing regions with even minor burning to be considered in our investigation of seasonality. In this study, we refer to the burned area data set processed in this way as "normalized burned area." We examine global normalized burned area in each region (Sect. 2.1; Fig. 1) using the method described below. 

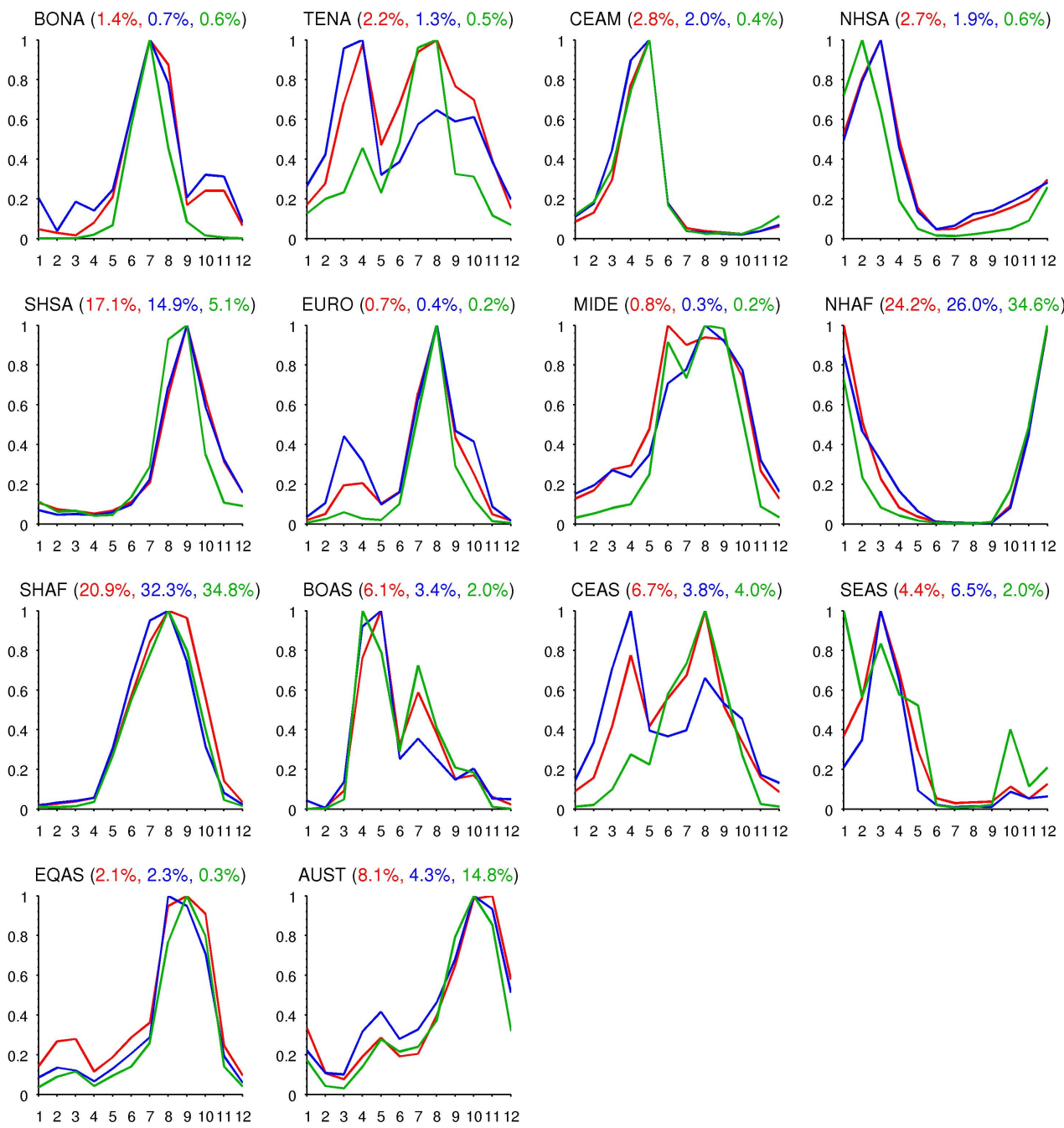

Fig. 2. Burned area from GFED (green) and fire counts from Terra MODIS (red) and Aqua MODIS (blue) for the regions in Fig. 1, normalized to the month of maximum burned area or fire counts. The $\mathrm{x}$-axis shows months, while the $y$-axis shows the scaled burned area and fire counts. The numbers in parentheses are the percent contributions of the total mean annual fire counts or burned area in the region to the global total mean annual fire counts or burned area, following the same color scheme as the lines in the plot.

\subsection{Attribution method}

For each region, we use a method that is based on a leastsquares analysis to determine the seasonality of burned area on agricultural and non-agricultural lands. In every grid cell, we assume that:

$p_{\mathrm{a}, i}+p_{\mathrm{n}, i}=1$

where $p_{\mathrm{a}, i}$ and $p_{\mathrm{n}, i}$ are the fractions of land area in grid cell $i$ that are agricultural and non-agricultural, respectively. The expected amount of fire in grid cell $i\left(E_{i}\right)$ is defined as:

$E_{i}=p_{\mathrm{a}, i} \bar{F}_{\mathrm{a}}+\left(1-p_{\mathrm{a}, i}\right) \bar{F}_{\mathrm{n}}$

where $\bar{F}_{\mathrm{a}}$ and $\bar{F}_{\mathrm{n}}$ represent the regionally-averaged (i.e., over all $N$ grid cells in the region) burned area in hypothetical grid cells that are completely agricultural or non-agricultural, respectively. For each month (120 in the study period) and land-use type, we find the sum of squared differences $(S)$ between $E_{i}$ and the observed burned area in each grid cell $i$ as:

$S=\sum_{i}^{N}\left[E_{i}-D_{i}\right]^{2}$

where $D_{i}$ represents the GFED burned area for the grid cell. The unknowns in this equation are $\bar{F}_{\mathrm{a}}$ and $\bar{F}_{\mathrm{n}}$. Our goal is to find values for these unknowns that minimize $S$. Essentially, we are unpacking the land-use specific signals from the burned area. 
To solve for the two unknowns $\left(\bar{F}_{\mathrm{a}}\right.$ and $\left.\bar{F}_{\mathrm{n}}\right)$, we set the partial derivative of $S$ with respect to $\bar{F}_{\text {n }}$ to zero such that:

$\frac{\partial S}{\partial \bar{F}_{\mathrm{n}}}=\sum_{i}^{N} 2\left[1-p_{\mathrm{a}, i}\right]\left[E_{i}-D_{i}\right]=0$.

This can be simplified to:

$\bar{F}_{\mathrm{a}}=\frac{\bar{D}}{\bar{p}_{\mathrm{a}}}+\left(1-\frac{1}{\bar{p}_{\mathrm{a}}}\right) \bar{F}_{\mathrm{n}}$

where $\bar{p}_{\text {a }}$ is the mean agricultural fraction, and $\bar{D}$ is the mean observed burned area. Taking the partial derivative with respect to $\bar{F}_{\text {a }}$ gives:

$\frac{\partial S}{\partial \bar{F}_{\mathrm{a}}}=\sum_{i}^{N} 2 p_{\mathrm{a}, i}\left[E_{i}-D_{i}\right]=0$.

Using Eq. (5), this can be simplified to:

$\bar{F}_{\mathrm{n}}=\bar{D}-\frac{\sigma_{p_{\mathrm{a}}, D}}{\sigma_{p_{\mathrm{a}}}^{2}} \bar{p}_{\mathrm{a}}$

where $\sigma_{p_{\mathrm{a}}}^{2}$ is the variance of $p_{\mathrm{a}}$, and $\sigma_{p_{\mathrm{a}}, D}$ is the covariance of $p_{\mathrm{a}}$ and $D . \bar{F}_{\mathrm{n}}$ is calculated explicitly from Eq. (7), and Eq. (5) can then be used to determine $\bar{F}_{\mathrm{a}}$.

We apply the method every month to the normalized burned area in every study region. When the calculations summarized by Eqs. (5) and (7) return values of $\bar{F}_{\mathrm{a}}<0$ or $\bar{F}_{\mathrm{n}}<0$, we apply the following conditional simplification to preserve realistically constrained values of $\bar{F}_{\text {a }}$ and $\bar{F}_{\mathrm{n}}$. If $\bar{F}_{\mathrm{a}}<0$, we set $\bar{F}_{\mathrm{a}}=0$ and re-calculate $\bar{F}_{\mathrm{n}}$ from Eq. (5). If $\bar{F}_{\mathrm{n}}<0$, we set $\bar{F}_{\mathrm{n}}=0$ and re-calculate $\bar{F}_{\mathrm{a}}$ from Eq. (5).

\subsection{Validation of the attribution method}

Under ideal conditions, we would test the above method by examining burned areas that we know correspond to agricultural and non-agricultural burning. This information is, however, the unknown for which we developed the method. We instead test it by masking the normalized burned area for two cases. In one case, all grid cells with non-agricultural fraction less than 0.8 are excluded; the burned area of the remaining grid cells are assumed to represent non-agricultural fire seasonality. In the second case, all grid cells with agricultural fraction less than 0.8 are excluded, with the burned area for the remaining grid cells assumed to represent agricultural fire seasonality. We chose $80 \%$ fractional coverage as the threshold based on the land-cover classification scheme for cropland discussed by Hansen et al. (2000). We will refer to this as the "subset method." Table 2 shows the fraction of grid cells in a region that qualify for each case, and the total number of grid cells in each region.

We examine each of the 14 regions separately, determining the mean burned area seasonality for the grid cells remaining after applying the threshold. As shown in Table 2,
Table 2. Fraction of the total number of grid cells in a region $(N)$ that are predominantly non-agricultural vegetation $\left(g_{\mathrm{n}}\right)$ and predominantly agricultural vegetation $\left(g_{\mathrm{a}}\right)$.

\begin{tabular}{lrrr}
\hline Region & $g_{\mathrm{n}}$ & $g_{\mathrm{a}}$ & $N$ \\
\hline BONA & 0.87 & 0.07 & 2651 \\
TENA & 0.24 & 0.30 & 2743 \\
CEAM & 0.17 & 0.14 & 928 \\
NHSA & 0.45 & 0.01 & 733 \\
SHSA & 0.35 & 0.10 & 4084 \\
EURO & 0.18 & 0.05 & 1898 \\
MIDE & 0.25 & 0.19 & 1313 \\
NHAF & 0.19 & 0.26 & 2630 \\
SHAF & 0.21 & 0.14 & 2858 \\
BOAS & 0.83 & 0.01 & 5673 \\
CEAS & 0.08 & 0.36 & 5172 \\
SEAS & 0.26 & 0.10 & 2050 \\
EQAS & 0.58 & 0.01 & 1032 \\
AUST & 0.05 & 0.05 & 2340 \\
\hline
\end{tabular}

the mean fraction of non-agricultural grid cells in a region is $0.34 \pm 0.25$, while the mean fraction of agricultural grid cells is $0.13 \pm 0.11$. These subsets of all grid cells in a region significantly reduce the sample size for regions such as AUST, EQAS, and NHSA, which is a limitation of the subset method.

The mean burned area seasonality value for each month and region is calculated as the mean of the seasonality value in that month for all $\mathrm{N}$ grid cells in the region over the ten years in the time series. There are a total of 168 mean fire seasonality values (12 months and 14 regions) for each of the two land-cover types. This is performed for seasonality values obtained using the attribution method described by Eqs. (5) and (7) and the subset method. Our goal is to test the attribution method. The correlation coefficients between the attribution method and the subset method results are always greater than 0.91 , which is significant with $p<0.05$. We conclude that the attribution method is an effective means to estimate fire seasonality on different land-cover types. From this point forward, we only refer to results from the attribution method (summarized by Eqs. 5 and 7).

\section{Results and discussion}

For the majority of the study regions, the agricultural fire season differs from the non-agricultural fire season (Fig. 3). These differences are broadly consistent with past studies of the human and physical drivers of global fires (e.g., Korontzi et al., 2006; Le Page et al., 2010).

To facilitate comparison of when fire is expected to occur and when it does occur, we have overlaid mean monthly flammability and lightning flash rate onto Fig. 3. Flammability is calculated using formulations described by Pechony and Shindell (2009) and depends on temperature, relative 

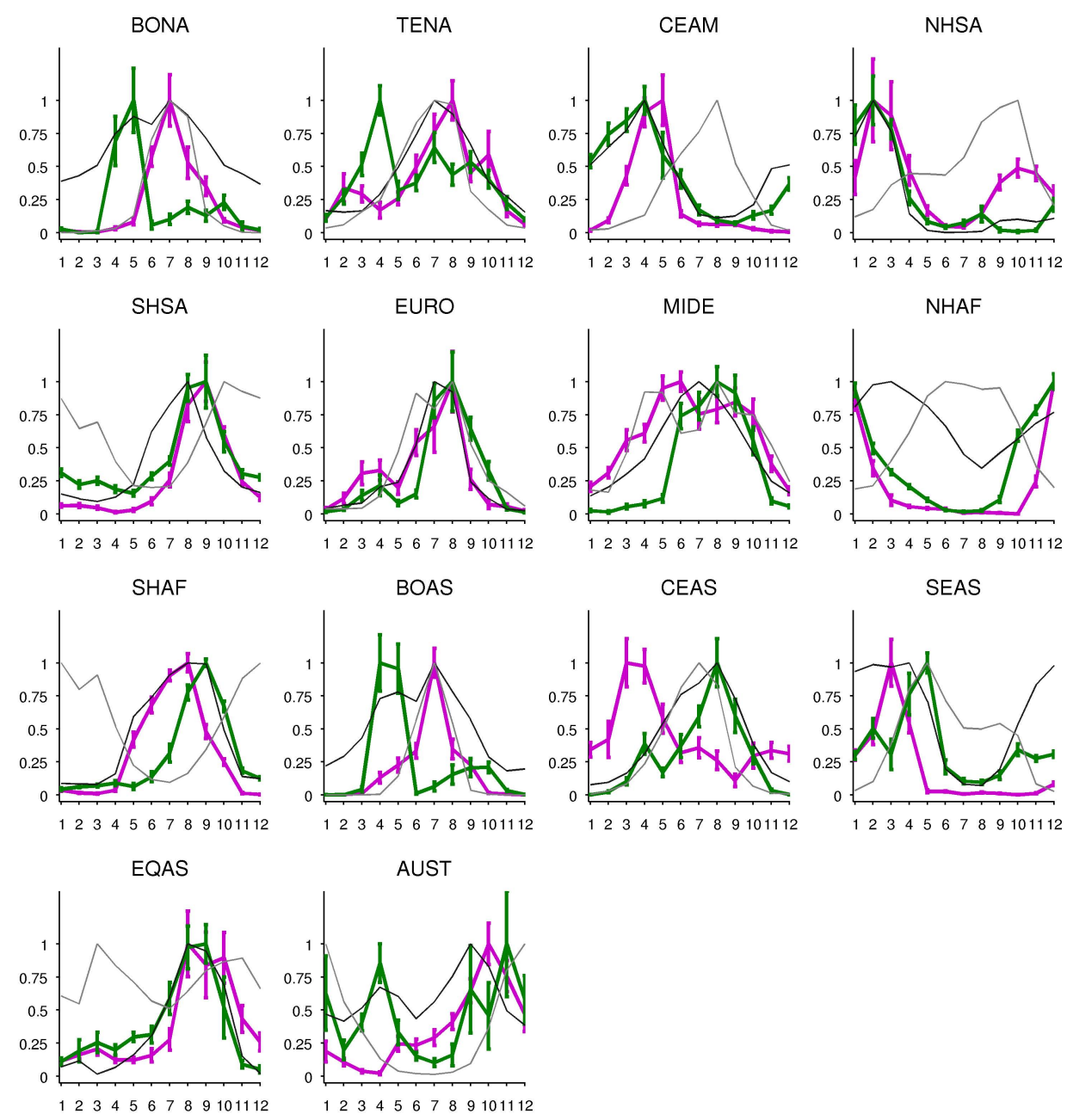

Fig. 3. Agricultural $\left(\bar{F}_{\mathrm{a}}\right.$, green $)$ and non-agricultural $\left(\bar{F}_{\mathrm{n}}\right.$, purple) fire seasonality derived from GFED for the regions in Fig. 1. The x-axis shows months and the y-axis shows $\bar{F}_{\mathrm{a}}$ and $\bar{F}_{\mathrm{n}}$ normalized to the maximum. The error bars indicate the interannual variability in $\bar{F}_{\mathrm{a}}$ and $\bar{F}_{\mathrm{n}}$ from 2000-2009. The dark gray line is the normalized flammability index, and the lighter gray line is the normalized lightning frequency.

humidity, and rainfall rate. Values of flammability close to one in Fig. 3 suggest a high susceptibility to fire ignitions provided fuel (vegetation) is available to burn and there is an ignition source (i.e., humans or lightning). Values close to zero indicate that ignition is unlikely. Temperature and relative humidity data are from the National Center for Environmental Prediction reanalysis product (Kalnay et al., 1996; downloaded from http://www.esrl.noaa.gov/psd/), while rainfall rate data are from the Global Precipitation Climatology Project version 2.2 (Huffman et al., 2009). Lightning flash rate is a combined data product based on observations from the NASA Lightning Imaging Sensor and Optical Transient Detector (Christian et al., 2003; downloaded from http://thunder.nsstc.nasa.gov/data/).

Figure 4 shows maps derived from the HYDE data (Klein Goldewijk et al., 2011; K. Klein Goldewijk, personal communication, 2012) of the 2000 to 2009 average (a) agricultural fraction of the land area and (b) fraction of agricultural area that is cropland as opposed to pasture. Agricultural fractions (Fig. 4a) are high throughout the world, with the exceptions being deserts, tropical rainforests, mountainous regions, and the boreal forests. Of the agricultural fraction of land, pasture usually dominates. The exceptions are the crop belts of the world, as discussed by Leff et al. (2004).

Below, we discuss the agricultural and non-agricultural fire seasonality for each of the 14 regions (Fig. 1), with section headings representing large multi-region areas. The sections are ordered from highest to lowest average annual burned area (Fig. 2, or Table 2 in Giglio et al., 2010). Generally, our results show that burning on non-agricultural lands depends more on weather than agricultural burning. The timing of agricultural burning depends on the needs of farmers and pastoralists (e.g., Vigilante et al., 2004; Laris and Wardell, 2006; McCarty et al., 2009), which we discuss on a per-region basis. 


\subsection{Sub-Saharan Africa (NHAF, SHAF)}

The non-agricultural fire season in Northern Hemisphere Africa (NHAF) begins around November-December and lasts through February, with a peak in December-January, corresponding roughly to the first half of a period of increased flammability (Fig. 3). The agricultural fire season peaks at the same time but begins about two months earlier in the dry season (Fig. 3). Previous work has shown that most of NHAF exhibits a fire season earlier than would be expected based on an index of fire weather alone (Laris and Wardell, 2006; Le Page et al., 2010), suggesting that earlier, less weather-dependent agricultural burning has influenced the overall fire seasonality in NHAF. Laris and Wardell (2006) discuss considerable cultural and physical evidence that early dry season fire is the dominant agricultural burning practice in the West African nations of Mali and Burkina Faso, mainly because fires are easier to control and trees are less likely to be killed if vegetation is burned before the peak of the dry season. Most agricultural land in this region is pasture (Fig. 4), and Korontzi et al. (2006) showed that cropland burning accounted for only about $2 \%$ of the MODIS-observed fires from 2001-2003, while savanna fires accounted for about $75 \%$. Results in this study thus agree with past studies and indicate that early dry season burning of agriculture - mostly pasture - is the dominant cause of fires in NHAF.

In Southern Hemisphere Africa (SHAF), we found that the non-agricultural fire season lasts from about May to October, while the agricultural fire season lasts from June to November with a smaller peak around March to April. The non-agricultural fire season in SHAF has the same shape as the agricultural fire season but is shifted about two months earlier, closely following increasing flammability (Fig. 3). Korontzi et al. (2006) found that cropland fires in SHAF occurred from about June to October and that August was the month of peak burning, which is not consistent with the peak value of agricultural burning from our results. However, cropland fires in SHAF contribute even less to burning than in NHAF, comprising only $1 \%$ of all fires while savanna fires make up $80 \%$ (Korontzi et al., 2006).

Like NHAF, SHAF agricultural land cover is mainly pasture (Fig. 4). Le Page et al. (2010) showed that across SHAF, the month of peak flammability ranged from July-August in the northwest (northern Angola) to November-December in the east and southeast (Mozambique, South Africa). The agricultural burning occurs in the latter half of a period of high flammability while lightning activity is increasing (Fig. 3). Le Page et al. (2010) also showed that SHAF experienced delayed overall burning (i.e., delayed with respect to flammability) along the southeastern coast; that region has a higher fraction of cropland than the rest of SHAF (Fig. 4), and this delay may partially account for our result of delayed agricultural burning. This suggests that the agricultural fire timing across SHAF is mostly due to burning practices in
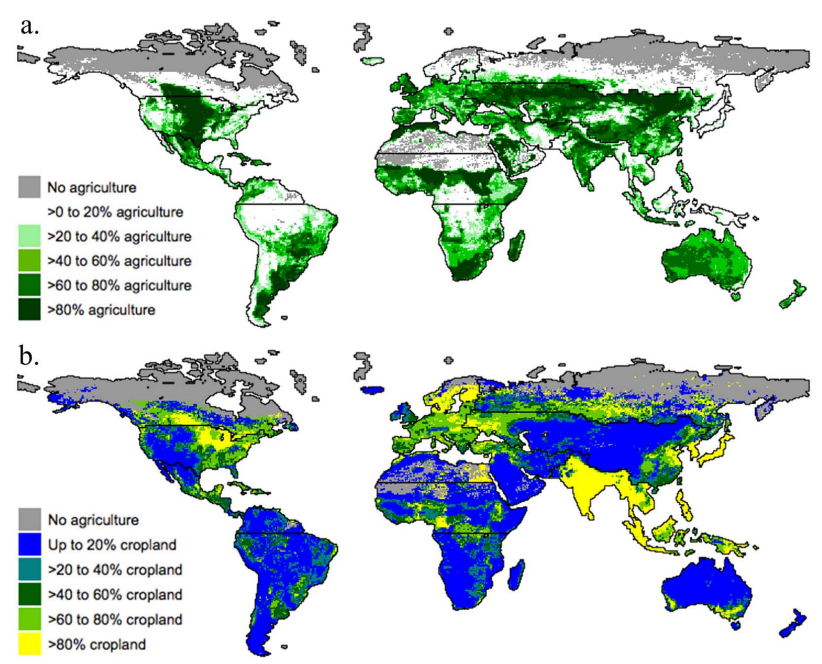

Fig. 4. Mean annual (2000-2009) land-use distributions from the HYDE 3.1 data set shown as (a) agricultural fraction of land area and (b) the composition of agricultural land as cropland versus pasture.

cropland; however, it is unclear why late dry season agricultural burning practices would be dominant in SHAF when early dry season agricultural burning practices are the norm in NHAF.

\subsection{Latin America (CEAM, NHSA, SHSA)}

Agricultural and non-agricultural burning in Central America (CEAM) both peak around April-May; however, the agricultural fire season begins earlier - in November-December, coincident with an increase in flammability (Fig. 3) - and ends later. In Mexico, Korontzi et al. (2006) found peak cropland burning in April-May, which they attribute to the harvest of maize, rice, sugarcane, and winter wheat. Since Mexico makes up much of the land area in CEAM and much agriculture in this region is comprised of croplands (Fig. 4), it is not surprising that we got a similar finding for CEAM's agricultural fire season there.

The beginning of the non-agricultural fire season closer to the period of peak flammability in CEAM suggests that nonagricultural burning depends on fuel having desiccated over much of the dry season, whereas agricultural burning takes place throughout the dry season (Fig. 3). Le Page et al. (2010) found delayed burning throughout most of CEAM, which our analysis suggests is non-agricultural (Fig. 3).

In Northern Hemisphere South America (NHSA), agricultural and non-agricultural burning are similar from January to August, but diverge from September through November. Non-agricultural lands experience a secondary peak in fires in October, while agricultural lands see a pronounced dip (Fig. 3). The February-March peak shared by agricultural and non-agricultural lands corresponds to a period of high flammability, while the secondary non-agricultural burning 
peak in October appears to be related to a peak in lightning frequency (Fig. 3). The agricultural fire seasons in CEAM and NHSA are similar, which corresponds to similar crop types between the two regions (Leff et al., 2004).

The agricultural and non-agricultural fire seasons in Southern Hemisphere South America (SHSA) correspond closely to trends in flammability. This agrees with findings by Le Page et al. (2010), which show that most of tropical SHSA exhibits no sign of a human impact on the fire season, although there are scattered zones of delayed fire seasonality. The agricultural fire season peaks around August-September (Fig. 3). This agrees well with previous work on cropland fire activity by Korontzi et al. (2006), who found peak burning late in the dry season. However, those authors also show that cropland burning accounts for only $2 \%$ of all fires in SHSA, while fire in grassland and savanna (where most pasture is located) accounts for about 50-60\%. This suggests that pasture might dominate the agricultural fire signal, but it happens that burning in pasture-rich regions of Brazil and Argentina tends to be similarly timed (Le Page et al., 2010). Our results agree with previous work suggesting that early dry season burning in this part of the region is limited (Le Page et al., 2010), unlike the heavily pastoral NHAF.

\subsection{Southeast Asia, Australia, and New Zealand (SEAS, EQAS, AUST)}

In Southeast Asia (SEAS), most agricultural burning takes place in April and May, with a more minor peak around October. Agriculture in this region is dominated by croplands, most of which are concentrated in India and Bangladesh (Fig. 4). Previous analyses of agricultural fire seasonality in India have found similar patterns. Korontzi et al. (2006) showed that most cropland fires occurred from April to June, which those authors associated with the sorghum harvest in central India. Le Page et al. (2010) also found April-May and October-November peaks in overall burning for an especially cropland-rich part of northern India, which they attributed to the wheat and rice harvests, respectively. Thus, it appears that agricultural burning practices in India (or practices that are similarly timed) dominate the agricultural fire signal for the entire region. This is distinct from the nonagricultural fire season, which lasts from about January to April.

The peaks of the agricultural and non-agricultural fire seasons in Equatorial Asia (EQAS) are similar, but the former begins around May while the latter begins closer to July (Fig. 3). Both peak in August, which corresponds to maximum flammability (Fig. 3). However, Le Page et al. (2010) found that the fire season throughout most of this region was delayed by at least 30 days compared to flammability conditions. Most likely, the differences between our studies are an artifact of slight differences in calculation and interpretation of flammability. For example, we include rainfall rate in our flammability calculation (per Pechony and Shindell,
2009) whereas Le Page et al. (2010) do not. Rainfall rates are relatively high in EQAS (not shown), and as such this difference in method might be important. Furthermore, while our methods seem to have resulted in similar timing of peak seasonality across the region as a whole, Le Page et al. (2010) did not consider peak flammability but rather the middle of a "season" of high flammability.

Analysis of fires in Australia and New Zealand (AUST) reveals two similarly strong agricultural fire seasons, one peaking in April and the other in November. The April peak corresponds to a period of somewhat elevated flammability, while the November peak in burning occurs as flammability nears its minimum after a September peak (Fig. 3). Korontzi et al. (2006) found that cropland burning in southern Australia peaks from March to May, which corresponds to the agricultural fire season that we estimated. However, Australia is characterized by extensive pasture (Fig. 4), and thus agricultural burning is probably dominated by pastoral management practices - indeed, the number of cropland fires here is very small compared to those in savannas or grasslands (Korontzi et al., 2006). Vigilante et al. (2004) discuss the complex fire management of northern Australian pastures and point out that while early dry season burning practices (March to May) are certainly common, late dry season fire use (October to November) is also extensive. This latter custom can be attributed mainly to Aboriginal pastoralists who prefer to wait for the dense grasses on fertile soils to fully dry before igniting fires that, as a result, are larger and more intense (Vigilante et al., 2004). Our results in AUST agree, providing strong evidence of extensive late dry season agricultural burning that is mainly due to pasture fires.

The non-agricultural fire season in AUST shows a pronounced dip in April that unexpectedly corresponds to a small peak in flammability (Fig. 3). However, the nonagricultural peak does come during the late dry season, when lightning frequency increases and vegetation is still relatively flammable (Fig. 3). Overall, the main non-agricultural fire season has the same shape as the agricultural fire season, but is shifted one month earlier. They also differ in that the nonagricultural burning dip corresponds to one of the agricultural burning peaks (Fig. 3).

\subsection{Boreal and Central Asia (BOAS, CEAS)}

Agricultural burning in BOAS takes place in two different seasons, with a major peak around April to May and a minor peak from August to October (Fig. 3). The first peak corresponds to a period of elevated flammability, and the second occurs as flammability approaches its minimum (Fig. 3). This fits well with a previous finding that cropland fires occur in April-May with a second peak occurring in AugustOctober (Korontzi et al., 2006), bracketing the period of maximum flammability in the region (Fig. 3). On the other hand, non-agricultural burning in BOAS (May to September with a July peak) corresponds very closely to the period of 
maximum flammability and lightning activity (June to August; Fig. 3).

Like BOAS, CEAS experiences a biennial agricultural fire season, with a major peak around August and a minor peak around April (Fig. 3). Korontzi et al. (2006) found similar timing and relative magnitude for cropland fires in Ukraine (part of CEAS). Although those authors found that cropland fire seasons in the broader CEAS region were similarly timed but opposite in magnitude, the fact that our results for agricultural burning in CEAS as a whole match those for Ukraine suggests that cropland fires in that country dominate the overall agricultural signal across the region. Indeed, Korontzi et al. (2006) attributed about $30 \%$ of the fires in CEAS to cropland fires.

Non-agricultural fire in CEAS shows a very different pattern, peaking around March-April and July-August, although such burning does take place at some level throughout the year (Fig. 3). We would expect non-agricultural fire seasonality to be closely tied to the peaks of flammability and lightning activity from June to August, but our results suggest this is not the case. Le Page et al. (2010) found the middle of the flammability and overall fire seasons to vary widely across this region, the latter from February in southern China to October in Kazakhstan. A more detailed analysis of the spatial distribution of burning and agriculture within CEAS might help explain the timing of non-agricultural burning in different parts of the region.

\subsection{North America (BONA, TENA)}

Agricultural burning peaks in April and May for temperate and boreal North America, respectively (TENA and BONA; Fig. 3). This is consistent with an April to June peak in North American cropland fires identified by Korontzi et al. (2006). However, this burning takes place about 2-3 months earlier than the peak period of flammability and lightning activity (Fig. 3). Our results also show evidence of a lower-amplitude but broader peak in agricultural burning from July to October, which previous researchers have associated with crop harvest (Korontzi et al., 2006; McCarty et al., 2009). Some of this burning takes place at the end of the high flammability season, but it extends well into a period of low flammability (Fig. 3). However, the strength of the first agricultural fire peak corresponds well to previous observations that the overall fire season in much of the cropland belt that extends from the Ohio River Valley in the United States to southern Canada occurs in April to May, about 50-150 days earlier than would be expected based on weather conditions alone (Le Page et al., 2010). Thus, our results support the idea that agricultural burning practices depend more on crop cycles than flammability (McCarty et al., 2009).

The non-agricultural fire seasons in North America last from about June to October, with a July peak in BONA and an August peak in TENA (Fig. 3). These are quite distinct from those regions' agricultural fire seasons, and are consistent with work finding that the boreal forests of Canada are most vulnerable to fire during the warmer summer months during which flammability and lightning frequency are at their maximum (Turetsky et al., 2011; Fig. 3). However, the timing we found for the non-agricultural fire season does not exactly match that of Le Page et al. (2010), who calculated it as later than July, and even as late as January, in many parts of BONA.

\subsection{Europe and Middle East (EURO, MIDE)}

The agricultural and non-agricultural fire seasons in Europe (EURO) are similar in terms of timing of minimum and maximum activity, but non-agricultural burning climbs steadily from January through its peak, whereas agricultural burning experiences a minor peak in April followed by a dip and then a sharp increase moving into July (Fig. 3). Mixed results in this region for the timing of overall burning relative to flammability (Le Page et al., 2010) supports our finding of similarly-timed fire seasons. Cropland comprises $50 \%$ or more of agricultural area in most of Europe (Fig. 4), so it is not surprising that the timing of the main agricultural fire season peak and the more minor March-April peak we see both agree with the seasonality of cropland fires in Europe discussed by Korontzi et al. (2006).

The agricultural fire season in the Middle East (MIDE) lasts from May to November (Fig. 3). Yevich and Logan (2003) point out that farmers in Turkey, which has a high cropland fraction (Fig. 4), traditionally burn crop residues in the field. The winter wheat crop in the Middle East is planted from September to December and harvested from April to August (Leff et al., 2004), which is entirely consistent with our results. Namely, agricultural fires begin in June (after harvest) and end by November (before planting; Fig. 3). Burning practices associated with pasture in other parts of MIDE (e.g., the Arabian Peninsula and the Mediterranean coast of Africa; Fig. 4) have not been well characterized in the literature.

The non-agricultural fire season in MIDE lasts from approximately March through October with a broad peak around May-June, corresponding to elevated levels of flammability and lightning frequency (Fig. 3).

\section{Conclusions}

Agricultural practices around the world have resulted in differences between the fire seasons associated with agriculture and those not associated with agriculture; we provide evidence for such differences in nearly every inhabited region on Earth (Fig. 3). We show that it is possible, using a concise algorithm, to decouple the agricultural and non-agricultural fire seasons by analyzing land-use data in conjunction with fire observations. Although we focused our discussion on burned area from GFED (Giglio et al., 2010), we obtained 
broadly similar results using the fire count data sets from the NASA MODIS instruments (Fig. 2; Justice et al., 2002; Giglio et al., 2006a).

The method we used to separate the agricultural and nonagricultural fire seasons can be generalized to include additional land-use data. For example, deforestation is an important driver of fire in some regions (Morton et al., 2008); our method could be used to parameterize global fire models for this and significantly improve estimates of the timing and extent of fire there. Our method could also be used to distinguish between cropland versus pasture fire, providing an added dimension with respect to agricultural burning practices.

We perform our analysis in terms of broad study regions defined by past studies (e.g., Giglio et al., 2006b), but examination of the results suggests that the regions are often too large and simply defined. This leads to a mix of biomes and agricultural practices that increase the complexity of physical interpretation. The development of study regions for analyses of global fire patterns that are dependent on underlying land cover and land use may be a simple but critical step in advancing the modeling of global fires beyond dependence of seasonality on climate conditions (e.g., Pechony and Shindell, 2009; Kloster et al., 2010; Thonicke et al., 2010) to include dependence on well-documented cultural burning practices (e.g., Yevich and Logan, 2003; Vigilante et al., 2004; Laris and Wardell, 2006; McCarty et al., 2009).

Our results here prove that fires used for management of agriculture and fires on non-agricultural land can be distinguished in observational time series of overall burning, especially if regional differences are considered to account for unique cultural practices. This suggests that seasonalities of different fire types in large-scale models can be parameterized by and/or tested against real patterns. Incorporating such anthropogenic influences into regional and global models of fire and vegetation will advance the scientific understanding of fire in the Earth system, both in the past and the future.

Acknowledgements. BIM was supported by the Carbon Mitigation Initiative, Princeton, NJ, and by Departmental Funds from University of North Carolina at Charlotte Geography and Earth Sciences Department. SSR was supported by the Princeton University Department of Ecology \& Evolutionary Biology. The authors thank K. Klein Goldewijk for making updated HYDE 3.1 land-use data available.

Edited by: A. Arneth

\section{References}

Aldersley, A., Murray, S. J., and Cornell, S. E.: Global and regional analysis of climate and human drivers of wildfire, Sci. Total Environ., 409, 3472-3481, 2011.

Arora, V. and Boer, G.: Fire as an interactive component of dynamic vegetation models, J. Geophys. Res., 110, 1-20, 2005.

Christian, H. J., Blakeslee, R. J., Boccippio, D. J., Boeck, W. L., Buechler, D. E., Driscoll, K. T., Goodman, S. J., Hall, J. M., Koshak, W. J., Mach, D. M., and Stewart, M. F.: Global frequency and distribution of lightning as observed from space by the Optical Transient Detector, J. Geophys. Res., 108, 4005, doi:10.1029/2002JD002347, 2003.

Giglio, L., Csiszar, I., and Justice, C. O.: Global distribution and seasonality of active fires as observed with the Terra and Aqua MODIS sensors, J. Geophys. Res., 111, G02016, doi:10.1029/2005JG000142, 2006a.

Giglio, L., van der Werf, G. R., Randerson, J. T., Collatz, G. J., and Kasibhatla, P.: Global estimation of burned area using MODIS active fire observations, Atmos. Chem. Phys., 6, 957974, doi:10.5194/acp-6-957-2006, 2006b.

Giglio, L., Loboda, T., Roy, D. P., Quayle, B., and Justice C. O.: An active-fire based burned area mapping algorithm for the MODIS sensor, Remote Sens. Environ., 113, 408-420, doi:10.1016/j.rse.2008.10.006, 2009.

Giglio, L., Randerson, J. T., van der Werf, G. R., Kasibhatla, P. S., Collatz, G. J., Morton, D. C., and DeFries, R. S.: Assessing variability and long-term trends in burned area by merging multiple satellite fire products, Biogeosciences, 7, 1171-1186, doi:10.5194/bg-7-1171-2010, 2010.

Hansen, M., Defries, R. S., Townshend, J. R. G., and Sohlberg, R.: Global land cover classification at $1 \mathrm{~km}$ spatial resolution using a classification tree approach, Int. J. Remote Sens., 21, 1331-1364, 2000.

Huffman, G. J., Adler, R. F., Bolvin, D. T., and Gu, G.: Improving the global precipitation record: GPCP Version 2.1, Geophys. Res. Lett., 36, L17808, doi:10.1029/2009GL040000, 2009.

Justice, C. O., Giglio, L., Korontzi, S., Owens, J., Morrisette, J. T., Roy, D., Descloitres, J., Alleaume, S., Petitcolin, F., and Kaufman, Y.: The MODIS fire products, Remote Sens. Environ., 83, 244-262, 2002.

Kalnay, E., Kanamitsu, M., Kitsler, R., Collins, W., Deaven, D., Gandin, L., Iredell, M., Saha, S., White, G., Woollen, J., Zhu, Y., Chelliah, M., Ebisuzaki, W., Higgins, W., Janowiak, J., Mo, K. C., Ropelewski, C., Wang, J., Leetmaa, A., Reynolds, R., Jenne, R., and Joseph, D.: The NCEP/NCAR 40-year reanalysis project, B. Am. Meteorol. Soc., 77, 437-470, 1996.

Klein Goldewijk, K., Beusen, A., van Drecht, G., and de Vos, M.: The HYDE 3.1 spatially explicit database of human-induced global land-use change over the past 12,000 years, Global Ecol Biogeogr., 20, 73-86, 2011.

Kloster, S., Mahowald, N. M., Randerson, J. T., Thornton, P. E., Hoffman, F. M., Levis, S., Lawrence, P. J., Feddema, J. J., Oleson, K. W., and Lawrence, D. M.: Fire dynamics during the 20th century simulated by the Community Land Model, Biogeosciences, 7, 1877-1902, doi:10.5194/bg-7-1877-2010, 2010.

Korontzi, S., McCarty, J., Loboda, T., Kumar, S., and Justice, C.: Global distribution of agricultural fire in croplands from 3 years of Moderate Resolution Imaging Spectroradiometer (MODIS) data, Global Biogeochem. Cy., 20, GB2021, 
doi:10.1029/2005GB002529, 2006.

Krawchuk, M. A., Moritz, M. A., Parisien, M.-A., Van Dorn, J., and Hayhoe, K.: Global Pyrogeography: the Current and Future Distribution of Wildfire, PloS ONE, 4, e5102, doi:10.1371/journal.pone.0005102, 2009.

Laris, P. and Wardell, D. A.: Good, bad or "necessary evil?" Reinterpreting the colonial burning experiments in the savanna landscapes of West Africa, Geogr. J., 172, 271-290, 2006.

Le Page, Y., Oom, D., Silva, J. M. N., Jönsson, P., and Pereira, J. M. C.: Seasonality of vegetation fires as modified by human action: Observing the deviation from eco-climatic fire regimes, Global Ecol. Biogeogr., 19, 575-588, 2010.

Leff, B., Ramankutty, N., and Foley, J. A.: Geographic distribution of major crops across the world, Global Biogeochem. Cy., 18, GB1009, doi:10.1029/2003GB002108, 2004.

McCarty, J. L., Korontzi, S., Justice, C. O., and Loboda, T.: The spatial and temporal distribution of crop residue burning in the contigrous United States, Sci. Total Environ., 407, 5701-5712, doi:10.1016/j.scitotenv.2009.07.009, 2009.

Morton, D. C., Defries, R. S., Randerson, J. T., Giglio, L., Schroeder, W., and van der Werf,G. R.: Agricultural intensification increases deforestation fire activity in Amazonia, Glob. Change Biol., 14, 2262-2275, doi:10.1111/j.13652486.2008.01652.x, 2008.

Pechony, O. and Shindell, D. T.: Fire parameterization on a global scale, J. Geophys. Res., 114, D16116, doi:10.1029/2009JD011927, 2009.
Thonicke, K., Spessa, A., Prentice, I. C., Harrison, S. P., Dong, L., and Carmona-Moreno, C.: The influence of vegetation, fire spread and fire behaviour on biomass burning and trace gas emissions: results from a process-based model, Biogeosciences, 7 , 1991-2011, doi:10.5194/bg-7-1991-2010, 2010.

Turetsky, M. R., Kane, E. S., Harden, J. W., Ottmar, R. D., Manies, K. L., Hoy, E., and Kasischke, E. S.: Recent acceleration of biomass burning and carbon losses in Alaskan forests and peatlands, Nat. Geosci., 4, 27-31, doi:10.1038/ngeo1027, 2011.

van der Werf, G. R., Randerson, J. T., Giglio, L., Collatz, G. J., Mu, M., Kasibhatla, P. S., Morton, D. C., DeFries, R. S., Jin, Y., and van Leeuwen, T. T.: Global fire emissions and the contribution of deforestation, savanna, forest, agricultural, and peat fires (19972009), Atmos. Chem. Phys., 10, 11707-11735, doi:10.5194/acp10-11707-2010, 2010.

Vigilante, T., Bowman, D. M. J. S., Fisher, R., Russell-Smith, J., and Yates, C.: Contemporary landscape burning patterns in the far North Kimberly region of north-west Australia: human influences and environmental determinants, J. Biogeogr., 31, 13171333, 2004.

Yevich, R. and Logan, J. A.: An assessment of biofuel use and burning of agricultural waste in the developing world, Global Biogeochem. Cy., 17, 1095, doi:10.1029/2002GB001952, 2003. 